pends on "soft" research grants instead of "hard" institutional funding. Nevertheless, says Hempel, people do not really get in each other's way.

National stereotypes have not been borne out aboard Polarstern, according to Hempel. "The Finns are sober, and the Italians are among the hardest workers", he says. Furthermore, adds Hempel, the Germans "behaved themselves" more cooperatively as hosts than they would have if they had been among themselves.

One of the strengths of the German polar research programme is interdisciplinary research. Hempel and others at AWI are quick to point out that understanding how creatures can live in the sea ice is intimately related to understanding how ice itself is formed. Every voyage of Polarstern leads to several unplanned collaborations among researchers of different disciplines, and often different countries, which Hempel views as a very healthy development.

The opportunity to do interdisciplinary research helps make up for what is seen as the major drawback of Polarstern: waiting for others to do their work. Geophysicists and bathymetrists, for example, must make their measurements from a moving ship, whereas biologists and oceanographers usually re- quire the ship to stand still while they take samples.

Having a number of smaller ships would make it possible for each group to spend more time doing what it came for. But being able to break ice up to one metre thick - and therefore to work in winter - help make $\mathrm{Po}$ larstern a favourite among German polar researchers, who by now make up three-quarters of the ship's users.

The interdisciplinary approach also characterizes AWI itself, which was founded in 1980 as the newest, and smallest, of Germany's 13 national laboratories (Grossforschungseinrichtungen). With a staff of 300 to do research on both poles as well as the ocean, AWI is one of the largest multidisciplinary polar research institutes in the world.

AWI was founded in part to give Germany more of a say in Antarctic affairs. By building a year-round research station, Georg von Neumayer near the Weddell Sea, Germany was able to become a signatory to the Antarctic treaty. AWI is both a logistical and scientific base for the station, which has a crew of nine in winter.

But above all, it is Polarstern that has given Germany a greater say in international decisions on the direction of Antarctic research.

Steven Dickman

\section{Meteorites for all}

\section{London}

IN Antarctic research as in many other fields, the European Communities' (EC) research programme is beginning to make its presence felt. Last September, the EC awarded a 400,000 ECU (about $£ 280,000$ ) three-year grant to the EUROMET project - a panEuropean effort to collect and study Antarctic meteorites and cosmic dust.

Antarctica yields a fruitful harvest for meteorite collectors, largely because meteorites are easier to spot on an ice sheet than on stony ground. Antarctic samples also include earlier meteorite falls (see page 300), and are less contaminated with terrestrial material. 'Clean' Antarctic meteorites provide an ideal opportunity to investigate the embryonic Solar System.

The United States and Japan have been collecting Antarctic meteorites for about 15 years. David Drewry, director of the BAS, says the United States and Japan have not kept a "stranglehold" on their collections, but European meteoriticists' requests for samples unavoidably take time to process. The EUROMET collection should relieve the pressure, and comes as the Japanese programme is in something of a hiatus, with no field expeditions due for several years.

Ian Franchi, from the Open University (OU), says the first EUROMET field season went well. Blessed by good weather, Franchi and four colleagues collected 264 meteorite fragments in the Frontier Mountains over three weeks straddling the new year. The samples will reach the OU at Milton Keynes in April. Shortly afterwards, a small working group will meet to assess the applications to work on the samples.

The EUROMET team's success in winning EC funding does not mean that 'open season' has been declared for Antarctic scientists to apply for EC money. The project was favoured because of its collaborative nature, involving 40 laboratories in 12 European countries, rather than its Antarctic location. The same goes for a previous major Antarctic project to win EC support: EPOS, a marine ecology expedition on board the German Polarstern research ship (see previous page) in the Antarctic summer of 1988-89, provided data for more than 100 scientists from eight EC countries, three other European states and Israel.

But further EC forays into Antarctic science are possible. The EC last year set up the European Committee on Ocean and Polar Science (ECOPS), run jointly with the European Science Foundation (ESF), to consider the potential for future European collaboration. Michele Fratta, from ESF, says ECOPS is now drawing up a proposal for a large European Antarctic ice-core drilling programme, to provide valuable palaeoclimatic data.
In addition to its possible role as a sink for carbon dioxide, the region is important because of its role in heat exchange between the ocean and the atmosphere. Sunlight in the tropics warms the ocean water, which flows slowly southward just below the surface until it reaches the Southern Ocean. At the same time, water from the north Atlantic is trans\section{over five years, in winter and in sum} five years, in winter and in sum the accuracy of this figure.

Another bonus will be the eagerly awaited opportunity to compare the modern flow rates with data from earlier geological ages, which have been determined by sampling the Southern Ocean bottom.
S.D. 